\title{
Proses Berpikir Kreatif Siswa SMP dalam Menyelesaikan Masalah Matematika Berdasarkan Gaya Belajar
}

\author{
Yohanes O. Jagom ${ }^{1}$, Irmina V. Uskono², Wilfridus B.N. Dosinaeng ${ }^{3}$, Meryani Lakapu ${ }^{4}$ \\ 1,2,3,4 Universitas Katolik Widya Mandira, Jln. San Juan No. 01. Penfui Timur. Kupang, NTT. \\ kraengyovanmgr@gmail.com
}

\begin{abstract}
Students'creative thinking processes need to be developed so that by developing creative thinking processes, students are able to generate new ideas in solving math problems. One of the reasons for the difficulty of students developing creative thinking processes is different learning styles, because differences in learning styles can affect students' understanding. This study aims to describe the creative thinking process of students in solving math problems based on learning styles. The subjects of this study were 3 students of SMPK St. Yosef Naikoten Kupang, each representing one subject of visual, auditory and kinesthetic learning styles. The results showed that at the preparation stage, subjects with visual, auditory, and kinesthetic learning styles were able to carry out the creative thinking process well, which was shown by expressing important ideas from the questions. In the incubation stage, subjects with visual, auditory, and kinesthetic learning styles are able to formulate ideas in solving problems by writing step by step. In the illumination stage, the subject of visual, auditory, and kinesthetic learning styles is able to express their ideas verbally well. And at the verification stage, the subject of visual and auditory learning styles always checks the answers that have been done, while the kinesthetic subjects have not been able to re-verify the results of the work done. Thus the visual and auditory subjects are able to produce creative thinking processes in solving mathematical problems based on the indicators developed by Wallas while the kinesthetic subjects have not been able to produce creative thinking processes in solving mathematical problems.
\end{abstract}

Keywords: Creative Thinking Process, Learning Style, Solving Mathematical.

\begin{abstract}
Abstrak
Proses berpikir kreatif siswa perlu dikembangkan sehingga dengan mengembangkan proses berpikir kreatif, siswa mampu menghasilkan gagasan baru dalam menyelesaikan masalah matematika. Salah satu penyebab kesulitan siswa mengembangkan proses berpikir kreatif yaitu gaya belajar yang berbeda-beda, karena perbedaan gaya belajar dapat mempengaruhi pemahaman siswa tersebut. Penelitian ini bertujuan untuk mendeskripsikan proses berpikir kreatif siswa dalam menyelesaikan masalah matematika berdasarkan gaya belajar. Subjek penelitian ini 3 orang siswa SMPK St. Yosef Naikoten Kupang dengan masing-masing mewakili satu subjek gaya belajar visual, auditory dan kinestetik. Hasil penelitian menunjukkan pada tahapan persiapan, subjek dengan gaya belajar visual, auditory, dan kinestetik mampu melaksanakan proses berpikir kreatif dengan baik yang ditunjukkan dengan mengungkapkan ide-ide penting dari soal. Pada tahap inkubasi subjek dengan gaya belajar visual, auditory, dan kinestetik mampu menyusun ide dalam menyelesaikan soal dengan menulis langkah demi langkah. Pada tahap iluminasi subjek gaya belajar visual, auditory, dan kinestetik mampu mengungkapkan idenya secara verbal dengan baik. Serta pada tahapan verifikasi subjek gaya belajar visual dan auditory selalu memeriksa kembali jawaban yang telah dikerjakan sedangkan subjek kinestetik belum mampu melakukan verifikasi kembali terhadap hasil pekerjaan yang dilakukan. Dengan demikian subjek visual dan auditory mampu mengasilkan proses berpikir kreatif dalam menyelesaikan masalah matematika berdasarkan indikator yang dikembangkan oleh wallas sedangkan subjek kinestetik belum mampu mengasilkan proses berpikir kreatif dalam menyelesaikan masalah matematika Berdasarkan indikator yang dikembangkan oleh wallas.
\end{abstract}

Kata kunci: Proses Berpikir Kreatif, Gaya Belajar, Masalah Matematika

Copyright (c) 2021 Yohanes O. Jagom, Irmina V. Uskono, Wilfridus B.N. Dosinaeng, Meryani Lakapu $\triangle$ Corresponding author: Yohanes O. Jagom

Email Address: kraengyovanmgr@gmail.com (Jln. San Juan No. 01. Penfui Timur. Kupang, NTT, Indonesia)

Received 15 September 2020, Accepted 15 Maret 2021, Published 22 Maret 2021

\section{PENDAHULUAN}

Perkembangan revolusi industri 4.0 yang begitu pesat memberikan dampak yang sangat besar bagi perubahan dunia pendidikan. Secara umum dapat dilihat dari banyaknya pemanfaatan teknologi 
Proses Berpikir Kreatif Siswa SMP Dalam Menyelesaikan Masalah Matematika Berdasarkan Gaya Belajar, Yohanes O.

dalam pelaksanaan kegiatan pembelajaran. Guru sebagai garda terdepan dalam dunia pendidikan harus mampu dan tanggap serta sigap dalam menghadapi era revolusi industri 4.0 dengan menggunkan cara atau metode yang tepat sehingga selalu mengupgrade kompetensi dalam menghadapi era pendidikan revolusi 4.0. Salah satu cara yang wajib diperhatikan yaitu mengembangkan pola berpikir kreatif siswa sehingga siswa mampu mengelola kemampuan yang dimiliki dengan baik.

Pengembangan pola berpikir kreatif siswa merupakan startegi yang wajib dilakukan guru terlebih khusus dalam menyelesaikan masalah matematika sehingga siswa mampu berpikir lancar, luwes, melakukan elaborasi dan memiliki nilai orisinalitas dalam menjawab persoalan yang diselesaikan (Marliani, 2015). Berpikir kreatif merupakan perwujudtan dari berpikir tingkat tinggi, hal tersebut dikarenakan kemampuan berpikir merupakan keterampilan kognitif tertinggi yang wajib di kuasai oleh siswa dalam kegiatan pembelajaran (Siswono, 2018).

Berpikir kreatif merupakan aktivitas mental dalam menghasilkan ide-ide, gagasan, pemecahan masalah, maupun menemukan pola tertentu yang saling berkaitan antara satu dengan yang lainnya dalam menemukan makna (Marliani, 2015). Dalam menciptakan pemikiran yang kreatif perlu kebebasan dalam berpikir tanpa tekanan atau dibawah control (Mawanto, Siswono, \& Lukito, 2020). Berpikir kreatif dalam matematika sangat diperlukan dalam mencapai kompetensi dengan memperoleh sdan mengelolah informasi sehingga mampu menghasilkan solusi terhadap persoalan yang dihadapi. Oleh karena itu berpikir kreatif merupakan suatu aktivitas mental dalam menciptakan ide atau gagasan dalam menyelesaikan persoalan sehingga mampu memberikan solusi terhadap persoalan yang diselesaikan.

Proses berpkir kreatif merupakan kombinasi antara proses berpikir logis dan berpikir divergen (A. P. Sari \& Ikhsan, 2017). Berpikir logis lebih ditekankan pada kemampuan siswa dalam menarik kesimpulan sesuai dengan aturan logika dan dapat dibuktikan dengan kesimpulan yang benar berdasarkan pengetahuan-pengetahuan sebelumya sesuai dengan yang diketahui (Siswono, 2018). Sedangkan berpikir divergen menekankan pada kemampuan siswa dalam mencari berbagai alternatif jawaban terhadap suatu persoalan (Jagom, 2015). Proses berpikir kreatif matematis merupakan proses yang digunakan dalam menyelesaikan masalah dengan mengembangkan pola pikir yang terstruktur dengan mengacu pada sifat yang logis, didaktik dari daerah pengetahuan dan mengadaptasi koneksi ke konten matematika (Febriani \& Ratu, 2018). Proses berpikir kreatif siswa merupakan gambaran nyata bagaiaman munculnya kreativitas siswa dalam menyelesaikan masalah (Oktaviani, Sisworo, \& Hidayanto, 2018).

Namun pada kenyataanya proses berpikir kreatif siswa dalam kegitan pembelajaran matematika masih jarang diperhatikan oleh guru, guru hanya melihat hasil akhir dari penyelesaian siswa dalam menyelesaikan soal tanpa melihat proses yang dilakukan. Hal seperti ini membuat siswa kurang termotivasi dalam mengikuti kegiatan pembelajaran matematika yang mengakibatkan siswa tidak mampu mengembangkan kemampuan-kemampuan yang mereka miliki. Kendala lain yang menyebabkan kurangnya perhatian guru dalam mengembangkan proses berpikir kreatif siswa yaitu pembelajaran matematika yang masih relevan dengan pembelajaran konvensional, serta pembelajaran 
yang masih berpusat pada guru dan tidak menekankan pada proses berpikir kreatif siswa.

Selain itu sistem evaluasi yang digunakan hanya mengukur prestasi belajar seolah-olah pembelajaran matematika hanya melihat hasil bukan melihat proses. Dalam menumbuhkan dan mengembangkan proses berpikir kreatif siswa perlu diperkenalkan dengan masalah matematika yang menantang dan merangsang proses berpikir kreatif siswa. Hal ini bertujuan agar siswa mampu memahami, merancang, menyelesaikan serta menafsirkan solusi yang diperoleh berdasarkan informasi dan pengalaman yang dimiliki.

Dalam mengukur proses berpikir kreatif siswa menggunakan indikator yang dikembangkan oleh Wallas (Pangestu \& Hasti Yunianta, 2019) yang meliputi empat tahap yaitu, tahap persiapan, tahap inkubasi, tahap iluminasi, dan tahap verifikasi. Pertama tahapan persiapan dalam pemecahan masalah dengan mengumpulkan data, mencari pendekatan dan penyelesaian. Kedua tahapan inkubasi merupakan awal dari proses timbulnya inspirasi dan penemuan yang baru. Ketiga tahapan iluminasi merupakan menghasilkan suatu masalah berdasarkan ide dan gagasan baru. Keempat tahapan verifikasi merupakan menguji dan memeriksa hasil pemecahan masalah yang telah dilaksanakan.

Hal lain proses berpikir kreatif juga dapat dideskripsikan berdasarkan gaya belajar siswa. Setiap siswa mempunyai cara sendiri dalam memahami sutau konsep. Perbedaan gaya belajar masing-masing siswa dapat mempengaruhi terhadap pemahaman siswa tersebut. Siswa yang belajar dengan menggunakan gaya belajar yang lebih dominan akan memperoleh hasil yang baik jika dibandingkan jika siswa belajar dengan cara yang tidak sejalan dengan gaya belajar yang dimiliki. (A. K. Sari, 2014) menjelaskan gaya belajar siswa merupahan karakteristik dasar yang melekat dalam diri siswa berkaitan dengan menyerap, mengolah, dan menyampaikan informasi. (Wilyono, Liliasari, Setiawan, \& Paulus, 2012) Gaya belajar seseorang merupakan kombinasi yang dilakukan seseorang dalam menyerap dan mengatur serta mengelola informasi yang diterima. Selain itu (Karim, 2014) mengatakan gaya belajar merupakan cara siswa dalam menyerap, mengatur mengolah bahan informasi atau bahan pelajaran di pelajarai.

Selanjutnya (Sundayana, 2016) mengungkapkan bahwa gaya belajar merupakan kebiasaan siswa dalam memproses bagaimana menyerap informasi, pengalaman, serta kebiasaan siswa dalam memperlakukan pengalaman yang dimilikinya sehingga dapat digunakan sebagai dasar yang melekat dalam diri siswa. Berdasarkan uraian tersebut maka gaya belajar merupakan cara khas siswa dalam menyerap informasi, mengelola informasi, serta melakukan koombinasi terhadap informasi yang diperoleh sebagai bentuk pengalaman yang menjadi dasar dalam diri siswa. De Potter \& Harnik (dalam Papilayah \& Huliselan, 2016) menjelaskan secara umum gaya belajar dibedakan kedalam tiga kelompok besar, yaitu gaya belajar visual, gaya belajar auditori, dan gaya belajar kinestetik. Gaya belajar visual merupakan gaya belajar yang lebih menekanakan pada cara melihat, mengamati, memandang, dan sejenisnya. Kekuatan gaya belajar ini terletak pada inndra penglihatan.

Ciri-ciri gaya belajar matematika orang bertipe visual; rapih dan teratur dalam mempelajari matematika, teliti, mampu mengingat dengan baik asosiasi visual dalam pembelajaran matematika, baik 
Proses Berpikir Kreatif Siswa SMP Dalam Menyelesaikan Masalah Matematika Berdasarkan Gaya Belajar, Yohanes O. Jagom, Irmina V. Uskono, Wilfridus B.N. Dosinaeng, Meryani Lakapu

melalui tulisan di papan tulis, grafik, dan gambar, lebih suka membaca dari pada membacakan. Ciri-ciri belajar matematika orang bertipe auditorial; mudah terganggu oleh keributan, orang bertipe auditorial belajar dengan mendengarkan, oleh karena itu ia biasanya membutuhkan suasana yang jauh dari keributanuntuk belajar matematika dengan baik, dapat mengulang kembali apa yang dijelaskan oleh guru matematika secara lisan, dan suka berdiskusi. Ciri-ciri gaya belajar matematika orang bertipe kinestetik; belajar melalui manipulasi dan praktek atau latihan-latihan soal (Sirait, 2017). Oleh karena itu penelitian bertujuan untuk menggali proses berpikir kreatif siswa SMP dalam menyelesaikan masalah matematika berdasarkan gaya belajar.

\section{METODE}

Penelitian ini merupakan penelitian deskripsi eksploratif dengan analisi data menggunakan pendekatan kualitatif. Subjek dalam penelitan ini tiga orang siswa yang diukur menggunakan istrumen gaya belajar visuail, auditory dan kinestetik. Alat pengumpulan data berupa tes dan wawancara. Tes yang digunakan berupa tes uraian penyelesaian soal matematika tujuannya untuk mengetahui proses berpikir kreatif kemudian dilanjutkan dengan wawancara untuk menggali proses yang dilakukan dari tahapan-tahapan telah didilaksanakan. Selanjutnya untuk menguji kerdebilitas data dilakukan dengan menggunakan trianggulasi. Trianggulasi yang digunakan merupakan trianggulasi waktu. Prosedur yang dilakukan berupa tahan penyusunan istrumen penelitian berupa tes gaya belajar, tes penyelesaian masalah, dan pedoman wawan cara. Salanjutnya tahapan pelaksanaan kegiatan dan diakhiri dengan tahapan analisis data.

\section{HASIL DAN DISKUSI}

Hasil analisis data proses berpikir kreatif subjek yang bergaya belajar visual dalam menyelesaikan masalah matematika dapat dilihat pada gamabar berikut.

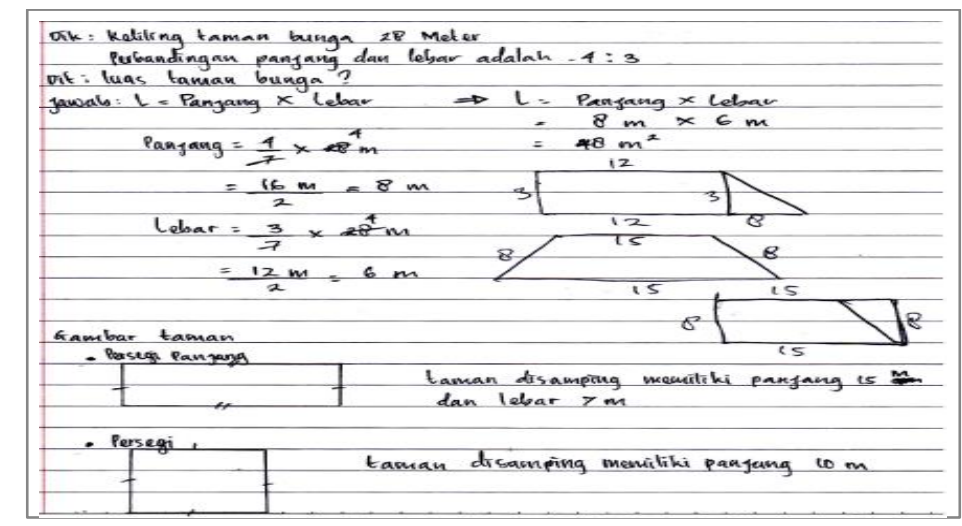

Gambar 1. Hasil pekerjaan subjek visual TPM 1

Berdasarkan hasil pekerjaan yang telah dilakukan oleh subjek visual dan dilanjutkan dengan wawancara terhadap hasil pekerjaan TPM I dan TPM II maka diperoleh hasil proses berpikir kreatif dalam menyelesaikan masalah matematika sebagai berikut; pada tahap persiapan subjek visual mampu 
menghasilkan berbagai macam jawaban dan dapat dibuktikan dengan benar, pada tahap inkubasi subjek mampu menghasilkan cara lain yang berbeda untuk mendapatkan satu bangun yang sudah didapat tanpa menggunakan rumus dan benar, pada tahap iluminasi subjek mampu menggambar bentuk bangun datar gabungan dan mampu menentukan sisi-sisi dari bangun tersebut kemudian menggunakan rumus dengan benar.

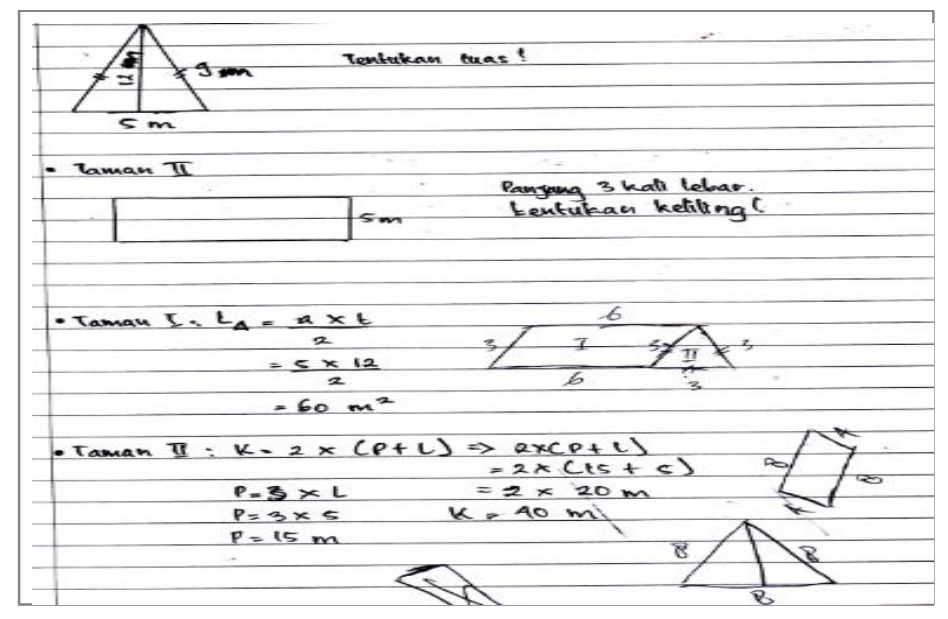

Gambar 2. Hasil pekerjaan subjek visual TPM II

Pada tahap verifikasi subjek mampu melakukan pemeriksaan kembali terhadap langkah-langkah yang telah dilakukan dalam menyelesaikan masalah yang diberikan. Hal ini sejalan dengan penelitian yang diungkapkan oleh (Khasanah, Sunardi, \& Sugiarti, 2018) siswa dengan gaya belajar visual mampu melewati setiap tahapan berpikir kreatif yang dikembangkan oleh Wallas dengan baik serta mampu memenuhi indikator-indikator dari proses berpikir kreatif. Berdasarkan penjabaran tersebut subjek visual mampu memenuhi keempat indikator dari proses berpikir kreatif dalam menyelesaikan masalah matematika yang dapat dijabarkan kedalam bentuk tabel berikut.

Tabel 1.Proses Berpikir Kreatif Subjek Gaya Belajar Visual

\begin{tabular}{|c|c|c|}
\hline Indikator & TPM I & TPM II \\
\hline Persiapan & $\mathrm{V}$ & $\mathrm{V}$ \\
\hline Inkubasi & $\mathrm{V}$ & $\mathrm{V}$ \\
\hline Iluminasi & $\mathrm{V}$ & $\mathrm{V}$ \\
\hline Verifikasi & $\mathrm{V}$ & $\mathrm{V}$ \\
\hline
\end{tabular}

Hasil analisis data proses berpikir kreatif subjek yang bergaya belajar auditory dalam menyelesaiakan masalah matematika dapat dilihat pada gambar 3 dan 4. Berdasarkan hasil pekerjaan yang telah dilakukan oleh subjek auditory dan dilanjutkan dengan wawancara terhadap hasil pekerjaan TPM I dan TPM II maka diperoleh hasil proses berpikir kreatif dalam menyelesaikan masalah matematika sebagai berikut; pada tahap persiapan subjek auditory mampu menghasilkan berbagai macam jawaban dan dapat dibuktikan dengan benar, pada tahap inkubasi subjek mampu menghasilkan cara lain yang berbeda untuk mendapatkan satu bangun yang sudah didapat tanpa menggunakan rumus dan benar, pada tahap iluminasi subjek mampu menggambar bentuk bangun datar gabungan dan mampu 
menentukan sisi-sisi dari bangun tersebut kemudian menggunakan rumus dengan benar.

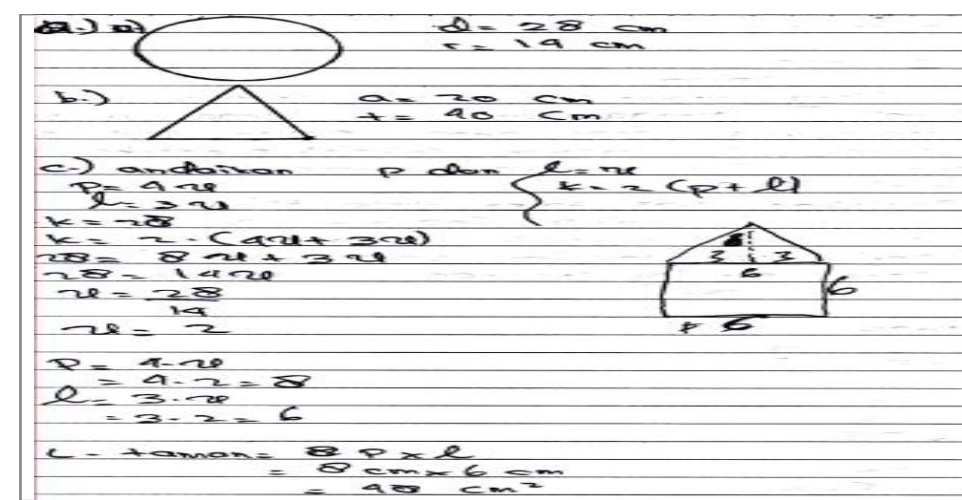

Gambar 3. Hasil pekerjaan auditory TPM I

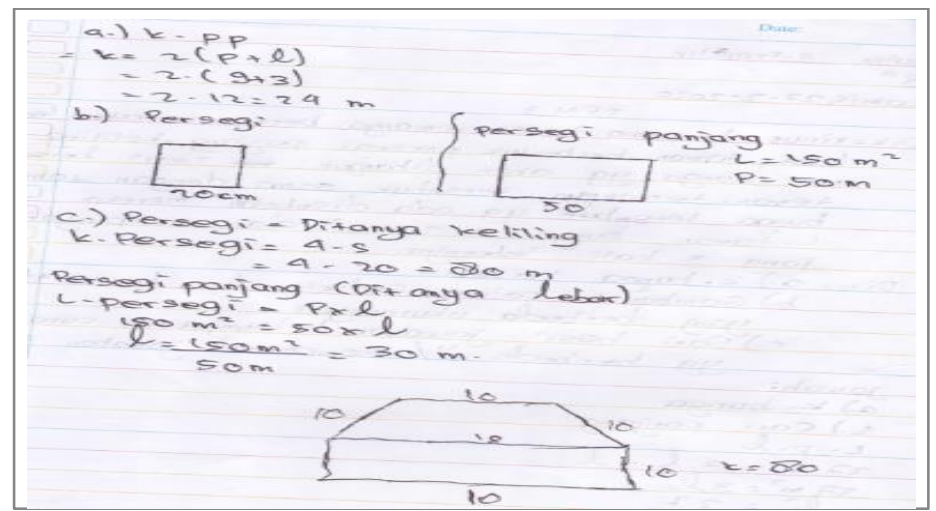

Gambar 4. Hasil pekerjaan auditory TPM II

Pada tahap verifikasi subjek mampu melakukan pemeriksaan kembali terhadap langkah-langkah yang telah dilakukan dalam menyelesaikan masalah yang diberikan. Berdasarkan penjabaran tersebut subjek auditory mampu memenuhi keempat indikator dari proses berpikir kreatif dalam menyelesaikan masalah matematika yang dapat dijabarkan kedalam bentuk tabel berikut.

Tabel 2. Proses Berpikir Kreatif Subjek gaya Belajar Auditory

\begin{tabular}{|l|c|c|}
\hline \multicolumn{1}{|c|}{ Indikator } & TPM I & TPM II \\
\hline Persiapan & $\mathrm{V}$ & $\mathrm{V}$ \\
\hline Inkubasi & $\mathrm{V}$ & $\mathrm{V}$ \\
\hline Iluminasi & $\mathrm{V}$ & $\mathrm{V}$ \\
\hline Verifikasi & $\mathrm{V}$ & $\mathrm{V}$ \\
\hline
\end{tabular}

Hasil analisis data proses berpikir kreatif subjek yang bergaya belajar kinestetik dalam menyelesaiakan masalah matematika dapat dilihat pada gambar 5 dan 6. Berdasarkan hasil pekerjaan yang telah dilakukan oleh subjek auditory dan dilanjutkan dengan wawancara terhadap hasil pekerjaan TPM I dan TPM II maka diperoleh hasil proses berpikir kreatif dalam menyelesaikan masalah matematika sebagai berikut; pada tahap persiapan subjek auditory mampu menghasilkan berbagai macam jawaban dan dapat dibuktikan dengan benar, pada tahap inkubasi subjek mampu menghasilkan cara lain yang berbeda untuk mendapatkan satu bangun yang sudah didapat tanpa menggunakan rumus 
dan benar, pada tahap iluminasi subjek mampu menggambar bentuk bangun datar gabungan dan mampu menentukan sisi-sisi dari bangun tersebut kemudian menggunakan rumus dengan benar.

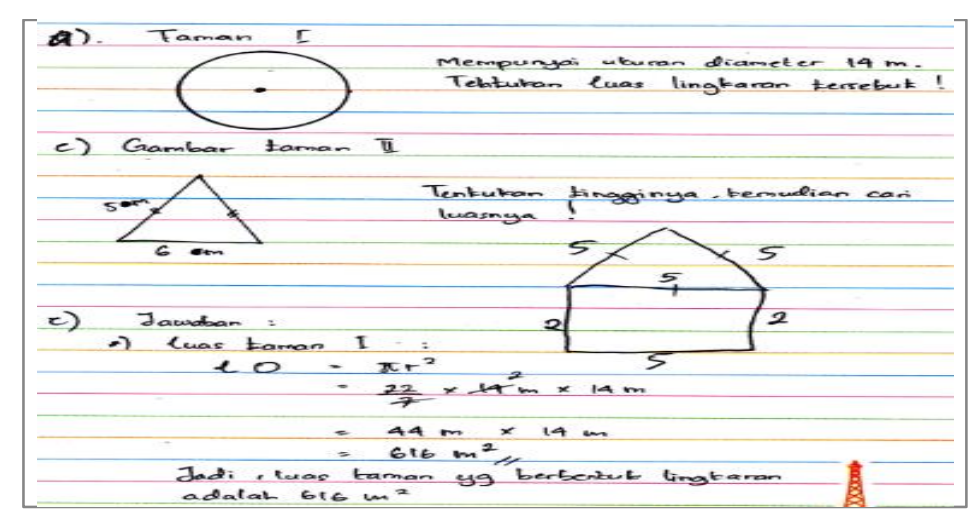

Gambar 5. Hasil pekerjaan kinestetik TPM I

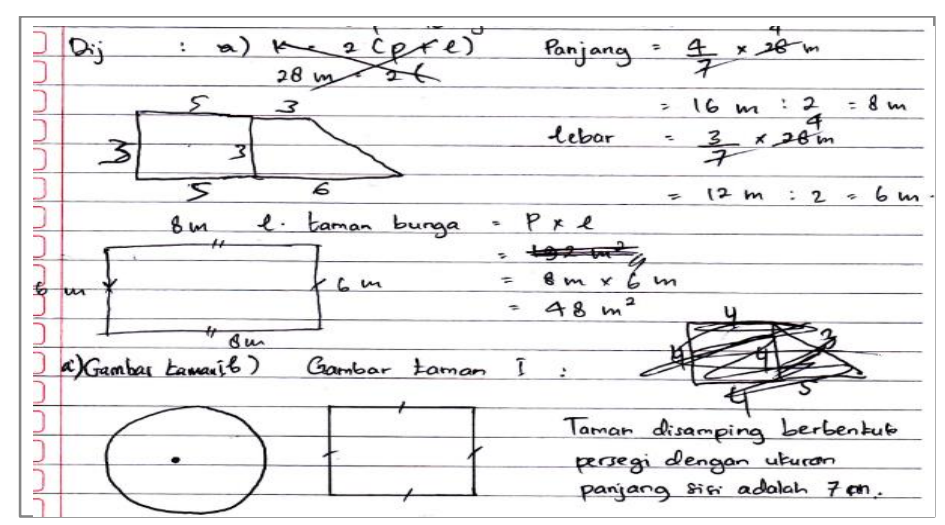

Gambar 6. Hasil pekerjaan kinestetik TPM II

Pada tahap verifikasi subjek belum mampu melakukan pemeriksaan kembali terhadap langkahlangkah yang telah dilakukan dalam menyelesaikan masalah yang diberikan. Berdasarkan penjabaran tersebut subjek auditory mampu memenuhi keempat indikator dari proses berpikir kreatif dalam menyelesaikan masalah matematika yang dapat dijabarkan kedalam bentuk tabel berikut.

Tabel 3. Proses Berpikir Kreatif Subjek Gaya Belajar Kinestetik

\begin{tabular}{|l|c|c|}
\hline \multicolumn{1}{|c|}{ Indikator } & TPM I & TPM II \\
\hline Persiapan & V & V \\
\hline Inkubasi & V & V \\
\hline Iluminasi & V & V \\
\hline Verifikasi & - & - \\
\hline
\end{tabular}

Berdasarkan hasil analisis data yang telah diuji, maka diperoleh gambaran proses berpikir kreatif dalam menyelesaikan masalah matematika dari subjek penelitian sesuai dengan gaya belajar masingmasing. Pada indikator persiapan subjek dengan gaya belajar visual, auditor dan kinstetik mampu menghasilkan proses berpikir kreatif dalam menyelesaikan masalah matematika yang telah diberikan dengan menghasilkan berbagai macam penyelesaian dan dapat dibuktikan kebenaran dari hasil 
Proses Berpikir Kreatif Siswa SMP Dalam Menyelesaikan Masalah Matematika Berdasarkan Gaya Belajar, Yohanes O.

pekerjaan yang dilakukan. Dengan demikian subjek dengan gaya belajar visual, auditori dan kinestetik memenuhi indikator persiapan dalam dalam proses berpikir kreatif. Hal ini sejalan dengan yang diungkapkan oleh (Aprianti, Sucipto, \& Kurniawati, 2020) ketiga subjek visual, auditori dan kinestetik mampu memahami soal dengan baik serta mampu menyusun rencana dalam menyelesaikan soal yang diberikan. Pada indikator inkubasi subjek dengan gaya belajar visual, auditor dan kinstetik mampu menghasilkan proses berpikir kreatif dalam menyelesaikan masalah matematika yang telah diberikan dengan mampu menghasilkan cara lain yang berbeda untuk mendapatkan satu bangun yang sudah didapat tanpa menggunakan rumus. Hal ini sesuai dengan yang dinyatakan oleh (Khasanah et al., 2018) ketiga subjek mampu mampu menemukan ide penyelesaian yang berbeda dalam menyelesaikan Masalah. Dengan demikian subjek dengan gaya belajar visual, auditori dan kinestetik memenuhi indikator inkubasi dalam proses berpikir kreatif.

Pada indikator iluminasi subjek dengan gaya belajar visual, auditor dan kinstetik mampu menghasilkan proses berpikir kreatif dalam menyelesaikan masalah matematika yang telah diberikan dengan mampu menggambar bentuk bangun datar gabungan dan menentukan sisi-sisi dari bangun tersebut kemudian menggunakan rumus. Selanjutnya bentuk seperti itu jarang dilakukan dan merupakan hal yang baru yang telah dilakukan oleh masing-masing subjek. Dengan demikian subjek dengan gaya belajar visual, auditori dan kinestetik memenuhi indikator iluminasi dalam dalam proses berpikir kreatif. Pada indikator verifikasi subjek deng an gaya belajar visual, auditor mampu melakukan pemeriksaan kembali terhadap langkah-langkah yang telah dilakukan dalam menyelesaikan masalah yang diberikan sedangkan subjek kinestetik belum mampu melakukan pemeriksaan kembali terhadap langkah-langkah yang telah dilakukan dalam menyelesaikan masalah yang diberikan. Hal ini sejalan dengan hasil penelitian (Khasanah et al., 2018) siswa dengan gaya belajar kinestetik hanya mampu melewati tiga tahapan berpikir kreatif wallas. Dengan demikian subjek dengan gaya belajar visual, auditori mampu memenuhi keempat tahap berpikir kreatif walas sedangkan dangaya belajar kinestetik hanya mampu memenuhi kega tahap berpikir kreatif wallas.

\section{KESIMPULAN}

Berdasarkan hasil analisis dan pembahasan maka dapat diambil kesimpulan bahwa proses berpikir kreatif siswa dalam menyelesaikan masalah matematika berdasarkan gaya belajar visual, auditory, dan kinestetik dapat dijabarkan sebagai berikut; Subjek dengan gaya belajar visual, dan auditory, mampu memenuhi keempat indikator proses berpikir kreatif yang dikembangkan oleh wallas yaitu ditunjukkan dengan menghasilkan banyak penyelesain dan dapat diuji kebenarannya serta mampu menghasilkan cara lain yang berbeda dan belum pernah dipelajari sebelumnya, selalu memeriksa kembali terhadap hasil pekerjaan yang telah dikerjakan. Sedangkan subjek dengan gaya belajar kinestetik hanya mampu memenuhi ketiga indikoator tahapan indikator berpikir kreatif yang di kembangkan wallas. Subjek kinestetik belum mampu melakukan verifikasi kembali terhadap pekerjaan yang telah dilakuakn. Dengan demikian perlu diperhatikan perkembangan proses berpikir kreatif dari masing-masing peserta 
didik menyelesaikanmasalah matematika.

\section{UCAPAN TERIMA KASIH}

Terimakasih peneliti ucapkan kepada semua pihak yang telah mendukung dan berpartisipasi dalam terlaksananya kegiatan penelitian sampai dengan dilakukannya publikasi.

\section{REFERENSI}

Aprianti, D. B., Sucipto, L., \& Kurniawati, A. R. K. (2020). Analisis Kemampuan Pemecahan Masalah Matematika Kelas VIII Berdasarkan Gaya Belajar. Paedagoria: Jurnal Kajian, Penelitian Dan Pengembangan Kependidikan, 11(3), 289-296. https://doi.org/https://doi.org/10.31764/paedagoria.v11i3.2662

Febriani, S., \& Ratu, N. (2018). Proses Berpikir Kreatif Matematis Siswa Dalam Pemecahan Masalah Open-Ended Berdasarkan Teori Wallas. Mosharafa: Jurnal Pendidikan Matematika, 7(1), 39-50. https://doi.org/DOI: https://doi.org/10.31980/mosharafa.v7i1

Jagom, Y. O. (2015). Kreativitas Siswa SMP Dalam Menyelesaikan Masalah Geometri Berdasarkan Gaya Belajar Visual-Spatial Dan Auditory-Squential. Math Didactic: Jurnal Pendidikan Matematika, 1(3), 176-190. https://doi.org/DOI : https://doi.org/10.33654/math.v1i3.18

Karim, A. (2014). Pengaruh Gaya Belajar dan Sikap Siswa Pada Pelajaran Matematika Terhadap Kemampuan Berpikir Kritis Matematika. Formatif: Jurnal Ilmiah Pendidikan MIPA, 4(3), 188195. https://doi.org/DOI : 10.30998/formatif.v4i3.154

Khasanah, U., Sunardi, \& Sugiarti, T. (2018). Proses Berpikir Kreatif Siswa Dalam Memecahkan Soal Cerita Pokok Bahasaan SPLDV Berdasarkan Tahapan Wallas Ditinjau Dari Gaya Belajar. Kadikma: Jurnal Matematika Dan Pendidikan Matematika, 9(2), 30-38. Retrieved from https://jurnal.unej.ac.id/index.php/kadikma/article/view/9705

Marliani, N. (2015). Peningkatan Kemampuan Berpikir Kreatif matematis Siswa Melalui Model Pembelajaran Missouri Mathematics Project (MMP). Formatif: Jurnal Ilmiah Pendidikan MIPA, 5(1), 14-25. https://doi.org/DOI : 10.30998/formatif.v5i1.166

Mawanto, A., Siswono, E. Y. T., \& Lukito, A. (2020). Pengembangan Media Cerita Menggambar Untuk Melatih Kemampuan Berpikir Kreatif Siswa Pada Materi Pecahan Kelas II. Jurnal Cendikia: Jurnal Pendidikan Matematika, 4(1), 424-437.

Oktaviani, M., Sisworo, \& Hidayanto, E. (2018). Proses Berpikir Kreatif Siswa Berkemampuan Tinggi dalam Menyelesaikan Soal Open-ended Berdasarkan Tahapan Wallas. Jurnal Pendidikan: Teori, Penelitian, Dan Pengembangan, 3(7), 935-944.

Pangestu, N. S., \& Hasti Yunianta, T. N. (2019). Proses Berpikir Kreatif Matematis Siswa Extrovert dan Introvert SMP Kelas VIII Berdasarkan Tahapan Wallas. Mosharafa: Jurnal Pendidikan Matematika, 8(2), 215-226. https://doi.org/10.31980/mosharafa.v8i2.472

Papilayah, J., \& Huliselan, N. (2016). IDENTIFIKASI GAYA BELAJAR MAHASISWA. Jurnal Psikologi Universitas Diponegoro, 15(1), 56-63. https://doi.org/DOI: 10.14710/jpu.15.1.56-63

Sari, A. K. (2014). Analisis Karakteristik Gaya Belajar VAK (Visual, Auditorial, Kinestetik) Mahasiswa Pendidikan Informatika Angkatan 2014. Edutic: Jurnal Pendidikan Dan Informatika, 1(1), 1-12. https://doi.org/DOI: https://doi.org/10.21107/edutic.v1i1

Sari, A. P., \& Ikhsan, M. (2017). Proses berpikir kreatif siswa dalam memecahkan masalah matematika 
Proses Berpikir Kreatif Siswa SMP Dalam Menyelesaikan Masalah Matematika Berdasarkan Gaya Belajar, Yohanes O. Jagom, Irmina V. Uskono, Wilfridus B.N. Dosinaeng, Meryani Lakapu

$\begin{array}{llll}\text { berdasarkan } \quad \text { model } & \text { Wallas. } & 10(1), & 18-32 .\end{array}$ https://doi.org/http://dk.doi.org./10.20414/betajtm.v10i1.102

Sirait, E. D. (2017). Pengaruh Gaya dan Kesiapan Belajar Terhadap Pemahaman Konsep Matematika Siswa. Formatif: Jurnal Ilmiah Pendidikan MIPA, 7(3), 207-218. https://doi.org/DOI : 10.30998/formatif.v7i3.2231

Siswono, T. (2018). Pembelajaran Matematika Berbasis Pengajuan dan Pemecahan Masalah. Bandung.

Sundayana, R. (2016). Kaitan antara Gaya Belajar, dan Kemampuan Pemecahan Masalah Siswa SMP dalam Pembelajaran Matematika. Mosharafa: Jurnal Pendidikan Matematika, 5(2), 75-84. https://doi.org/DOI: https://doi.org/10.31980/mosharafa.v5i2

Wilyono, K., Liliasari, Setiawan, A., \& Paulus, C. (2012). Model Multimedia Interaktif Berbasis Gaya Belajar untuk Meningkatkan Penguasaan Konsep Pendahuluan Fisika Zat Padat. Jurnal Pendidikan Fisika Indonesia, 8(1), 74-82. https://doi.org/10.15294/jpfi.v8i1.1995 